\title{
Children Protection Towards Dating Violence in Bengkulu
}

\author{
Zico Junius Fernando \\ Law Department \\ Bengkulu University \\ Bengkulu, Indonesia \\ zjfernando@unib.ac.id
}

\author{
Annisa Salsabila \\ Law Department \\ Bengkulu University \\ Bengkulu, Indonesia \\ annisasalsa2000@gmail.com
}

\begin{abstract}
Article 28B paragraph (2) of the 1945 Constitution of the Republic of Indonesia emphasized that every child has the right to live, grow and develop, then also has the right to have protection from violence and discrimination. These norms are further explained through Law Number 23 of 2002 as amended by Law Number 35 of 2014 concerning Child Protection. Practically, children are categorized as less than 18 years often experience dating violence in various forms, including physical, emotional, economic, sexual violence, to activity restrictions. It harms children's development that will determine the future of the nation. This study aims to describe the form of legal protection for children as victims of dating violence and to find obstacles of law enforcement for children victims of dating violence in Bengkulu. This study uses a juridical empirical (nondoctrinal) approach that observes the law in society with qualitative data analysis. This study showed that all types of dating violence which are classified as criminal acts can be subject to sanctions based on the provisions of the Child Protection Act and the Criminal Code if the perpetrator is more than 18 years old. However, in certain cases, such as fighting, children fighting over their boyfriends, or other minor violence, mediation is preferred as an alternative solution. There are obstacles in children's protection towards dating violence, including economic factors, immature feelings of children, low people's courage to make reports to law enforcers, lack of public knowledge, and the victim's sense of tolerance towards the perpetrator is still strong. This study encourages enhancement in preventive and repressive measures by law enforcers, as well as to increase the socialization of the law related to date violence issues which is not widely understood by the community, children in particular.
\end{abstract}

Keywords-Children, Dating Violence, Law Enforcers, Juridical Empirical.

\section{INTRODUCTION}

Children are a gift entrusted by God Almighty who has inherent dignity and worth as a whole human being. Every child has a dignity that deserves to be upheld and every child must get his rights without the child asking for it. For this reason, the potential of children needs to be developed as much as possible and protected from various acts of violence and discrimination so that the constitutional rights of children can be guaranteed and fulfilled to live, grow, develop, and participate optimally according to their abilities [1].

Constitutionally, children's rights are specifically regulated in Article 28B paragraph (2) of the 1945 Constitution of the Republic of Indonesia. The arrangements are also following the provisions within the Convention on the Rights of the Child which was ratified by the Government of Indonesia through Presidential Decree Number 36 of 1990 which states about general principles of child protection, which are non-discrimination, best interests of children, survival, and development, and respect for children's participation. The legal material regarding children's rights in the Convention on the Rights of the Child is constructed into 4 (four) categories of children's rights, which are:

- The survival rights, one of the children's rights stipulated by the Convention on the Rights of the Child which includes the rights to preserve and maintain life (the rights of life) and the rights to the highest standard of health and medical care attainable;

- The right to protection, one of the children's rights stipulated in the Convention on the Rights of the Child which includes the right to protection from discrimination, violence, and neglect for children who do not have families for refugee children;

- The right to grow and develop, one of the children's rights stipulated in the Convention on the Rights of the Child which includes all forms of education (formal and non-formal) and the right to achieve an adequate standard of living for physical, mental, spiritual, moral and social development of the child; 
- The participatory rights, one of the children's rights stipulated in the Convention on the Rights of the Child which includes the right of the child to express her/his views in all matters affecting that child [2].

These principles are also adopted within Law Number 23 of 2002 as amended by Law Number 35 of 2014 concerning Child Protection which was established by the government so that the fulfillment of children's rights can be implemented in Indonesia [3]. The background for the issuance of Law Number 23 of 2002 as amended by Law Number 35 of 2014 concerning Child Protection is because Indonesia guarantees the welfare of every citizen, including the protection of children's rights which are human rights as contained in the 1945 Constitution of The Republic of Indonesia and the United Nations Convention on the Rights of the Child [3].

The Convention on the Rights of the Child provides age limits for children, which is:

"For the convention, a child means every human being below the age of 18 years unless, under the law applicable to the child, the majority is attained earlier"'[4].

Which such understanding, means that the convention states that a child is classified under 18 years old, except under the law concerning children stipulated that the age of majority is reached earlier. Provision regarding age limit was also adopted in the Child Protection Law, including children who are still in the womb [1].

In this period of age, children also can categorize as teenagers undergoing many major and essential changes regarding the maturity of spiritual and physical functions, especially sexual functions [5]. During this period, adolescents experience puberty which makes them more likely to engage in dating activities with the opposite sex. Dating is a relationship between a man and a woman that is characterized by intimacy in which each other is involved in feelings of love and recognizes each other as a boyfriend/girlfriend. Whether we realize it or not, in the current era, many teenagers who are dating often conduct bad behaviors in relationships, one of those is dating violence. The definition of dating violence is violence towards couples who have not married yet, which includes physical, psychological, and economic violence. Below are forms of dating violence [6]:

- Physical violence such as hitting, slapping, kicking, pushing, extremely gripping on the partner's body, and other physical actions;

- Emotional or psychological abuse such as threatening, calling with names that embarrass partner in public space, vilify partner, and so on;
- Economic violence, such ask a partner to buy all the necessities of life in term utilizing or depleting a partner's wealth;

- Sexual violence, such as hugging, kissing, touching, or forcing for having sex under threats;

- Violence in terms of limiting activities by partners haunts many women in dating, such as a too possessive partner, too restrictive, often suspicious, always arrange our activities based on his/her will, up to being irritable and threatening.

Dating violence hinders law enforcement for the fulfillment of children's rights. Teenagers do not even realize that excessive jealousy, yelling, cursing, hitting, slapping, are not classified as love, but classified as dating violence that must be avoided. This phenomenon is certainly not in line with Article 28B paragraph (2) of the 1945 Constitution of the Republic of Indonesia which states "every child has the right to survive, grow and develop, and has the right to protection from violence and discrimination". Therefore, this study aims to look at 2 (two) things, which are (1) What are the forms of legal protection for children as victims of dating violence in Bengkulu, and (2) What are the obstacles in protecting children as victims of dating violence in Bengkulu.

\section{RESEARCH METHOD}

Essentially, research is an activity that seeks the truth of science, where research is born from doubts or curiosity about a problem [7]. This study uses an empirical (non-doctrinal) juridical approach that looks at the legal reality in society. Furthermore, qualitative data analysis was used. Qualitative data in this case using words, so the research report will contain data to provide an overview derived from interviews and some field notes.

\section{FINDING AND DISCUSSION}

\section{A. Legal Protection for Children as Victim of Dating Violence in Bengkulu}

1) Head of Women and Children Protection Unit (PPA) Bengkulu City Police Resort

Based on the interview on October 20, 2020, the Head of the Women and Child Protection Unit (PPA) of the Bengkulu City Police (or well known as POLRES) spells out that the PPA Unit does not handle relationships under 12 years old. PPA Unit only handles cases if there are criminal acts towards the perpetrator such as sexual abuse. The factors that caused dating violence include the victim having been sexually assaulted by the perpetrator, violence such as hitting, threats, the victim being blackmailed by asking the victim for money, and other actions that harm the victim. These cases can be legally prosecuted. 
PPA Unit said that they only straightened out the problems and made reconciliation between the parties for minor dating violence cases. After reconciliation, we declared it finished. The Head of the Women and Children Protection Unit (PPA) of Bengkulu City explained further that if the couple is over 18 years old, the punishment is referred to the Criminal Code (KUHP), Law Number 44 of 2008 concerning pornography. However, if the couple is under 18 years old, then Law Number 11 of 2012 concerning the Children Justice System is applied.

The Head of the Women and Children Protection Unit (PPA) of the Bengkulu City Police (POLRES) spells out that regarding provisions of the fines applied in articles 351, 352, and 354 of the Criminal Code have been updated in the Supreme Court of the Republic of Indonesia Regulation Number 2 of 2012 concerning Adjustment of Limits for Minor Crimes and Number of Fines in the Criminal Code, which essentially stipulates that "the maximum number of fines threatened in the Criminal Code except Article 303 paragraph 1 and paragraph 2, 303 in paragraph 1 and paragraph 2, is multiplied to 1,000 (one thousand) times. So for example, the fine in Article 351 paragraph (1) of the Criminal Code is Rp. 4.500,00 $\times 1.000$, which is IDR 4.500 .000 (four million five hundred thousand rupiahs)".

The Head of the Women and Children Protection Unit (PPA) of the Bengkulu City Police (POLRES) also explained that Law Number 44 of 2008 concerning Pornography, especially Articles 32 and 31 or the provisions of the Criminal Code do not strictly regulate dating violence. To anticipate this, it is necessary to conduct massive socialization. Effective and efficient socialization needs to be seen from the situation and condition of the community so that the aims of the socialization are right to target and successfully accepted by the public or the community.

The Binamitra which functions as Public Relations within the police, especially at the Bengkulu City Police Resort (POLRES) in carrying out its socialization uses an approach that is supported by the community. InLaw Number 2 of 2002 concerning the State Police of the Republic of Indonesia in Chapter III Article 13 states that the State Police of the Republic of Indonesia must maintain security and public order. It can be implied that the duties of the Police are not only as state institutions in charge of security services or legal protection but also work in social activities that prioritize humanitarian tasks.

Furthermore, the external public relations activity in the Binamitra of the Bengkulu City Police Resort (POLRES) aims to obtain a positive image and foster a positive attitude from the community in dealing with security issues. Various ways can be done in this socialization which includes the distribution of information evenly, active role and participation of the community, empowerment of important sectors such as natural resources and human resources that exist in each community's environment.

2) The prosecutor on State Attorney of Bengkulu

The State Attorney of Bengkulu urges that minor dating violence should be resolved through mediation. Violence in dating rarely occurs except consensual elements, but violence occurs usually due to the environment of the child and the way his parents educate the child, faith, and can be caused by insufficient economic factors so that the child falls into a deviant life. After dating violence involves obscenity, extortion, physical violence, threats to the child, then proceed to the article on the law of child protection.

All types of dating violence can be subject to criminal sanctions towards the person who commits it, if the children as the victim have not reached 18 years yet then the perpetrator can be charged with Article 76 $\mathrm{C}$ relating to Article 80 paragraph (1) Law Number 35 of 2014 concerning amendments to Law Number 23 of 2002 concerning Child Protection, stipulates that "Everyone is prohibited from placing, allowing, committing, ordering to do, or participating in violence towards children. Any person who violates the provisions as referred to Article $76 \mathrm{C}$ shall be convicted to a maximum imprisonment of 3 (three) years and 6 (six) months and/or a maximum fine of IDR 72,000,000.00 (seventy-two million rupiahs)". However, if the perpetrators are 18 years old or older, then you can claim on the persecution as regulated in Chapter XX of the Criminal Code (KUHP) such as Ordinary Persecution (Article 351 of the Criminal Code), Minor Persecution (Article 352 of the Criminal Code), and Severe Persecution (Article 354 of the Criminal Code) and other forms of violence can also be imposed such as obscenity (Article 289-296 of the Criminal Code), Sexual Harassment (Article 281-283) and for Crimes Against Modesty (Article 532-533), can also be charged with the Act Number 44 of 2008 concerning Pornography.

In addition, the State Attorney of Bengkulu has a program called the Prosecutor on the School/Jaksa Masuk Sekolah (JMS). A prosecutor on the School (JMS) was held to develop legal awareness for the community in general and students in particular and students should receive legal knowledge from an early age. A prosecutor on the School (JMS) also provides knowledge about violence in general and violence in dating among students in Bengkulu.

\section{3) Justice on Bengkulu District Court of Justice}

Society has often heard about so many cases of domestic violence. But, the occurrence of dating violence cases is rarely deemed as part of the violence. It is considered that it is a form of expression of love from their partner. This happens because most girls do not understand the form of violence they experience in a relationship so that girls do not realize that they have been victimized by their boyfriends or otherwise. 
Based on experience in handling dating violence at the Bengkulu District Court, most of the victims only realized they had become victims when the relationship had problems. The victim did not realize that her boy/girlfriend's actions were classified as violence. Victims often assume that it is a form of expression of affection, love, and various feelings of people when they are in love. When the victim understands that her partner's actions are a form of violence that can't be tolerated anymore, usually the partner takes intimidation, threats, and various acts of silence. Those actions are revealed as the court facts.

The above situation certainly needs serious attention, so that similar incidents do not repeatedly occur because this will have an impact on the future of the victims. The 1945 Constitution of the Republic of Indonesia as a basic foundation provides equal legal protection for women and men. Article 27 paragraph (1) states that all citizens are equal before the law and government and are obliged to uphold the law and government with no exceptions. This article emphasizes that all citizens have the same position under the law, including a girl and this principle is often referred to as the principle of equality before the law.

In addition, Indonesia has also ratified the Convention on the Elimination of All Forms of Discrimination against Women (CEDAW), which was promulgated as Law Number 7 of 1984. CEDAW regulates the obligations of participating countries to protect women in all fields, both in the legal and political fields, as well as economic, social, cultural, civil, and others. The following are the forms of violence against women that often occur and are tried in the Bengkulu District Court, which are:

- Physical violence such as hitting, slapping, kicking, pushing, extremely gripping on the partner's body and other physical actions;

- Emotional or psychological abuse such as threatening, calling with names that embarrass partner in public space, vilify partner, and so on;

- Economic violence, such ask a partner to buy all the necessities of life in term utilizing or depleting a partner's wealth;

- Sexual violence, such as hugging, kissing, touching, or forcing for having sex under threats;

- Violence in terms of limiting activities by partners haunts many women in dating, such as a too possessive partner, too restrictive, often suspicious, always arrange our activities based on his/her will, up to being irritable and threatening.

4) Non-Govermental Organization (NGO) Education Center for Women and Children/Pusat Pendidikan Perempuan dan Anak (PUPA)
Based on the interview on October 25, 2020, the following are some examples of behavioral characteristics of couples who are vulnerable to dating violence that occurred in Bengkulu from the observations of the Education Center for Women and Children (PUPA):

- Couples who are too jealous, even accusing their partner of having an affair without clear proof;

- Controlling their partner's life, controlling the way their partner dresses, forbid to meet family or friends, and always checking their partner's phone;

- Having an unpredictable temperament;

- Fear of getting angry when with a partner;

- Obligated to report to your partner if you want to travel;

- Threatening rudely if you do not comply with his wishes;

- Hit or hurt you physically;

- Forcing you to kiss, have sex, or any other sexual activity;

- Forcefully asking for some money, or asking to buy things;

- Does not allow his partner to end the relationship for various reasons;

- Build an opinion that the problems that occur between you are the fault of one partner, to make you feel guilty;

- Always apologize for the mistakes made, and promise to change, but the mistakes are repeated.

If any of the above points are being experienced, someone may be experiencing dating violence.

TABLE I. FORMS OF DATING ViOLENCE

\begin{tabular}{|l|l|l|}
\hline \multicolumn{1}{|c|}{ Physical } & \multicolumn{1}{|c|}{ Emotional } & \multicolumn{1}{c|}{ Sexual } \\
\hline Hit & $\begin{array}{l}\text { Hit Ignoring partner's } \\
\text { feelings }\end{array}$ & $\begin{array}{l}\text { Forcing a partner } \\
\text { to have sex }\end{array}$ \\
\hline Jolt & $\begin{array}{l}\text { Insulting partner's } \\
\text { opinion or principles }\end{array}$ & $\begin{array}{l}\text { Forcing a partner } \\
\text { to have sex without } \\
\text { contraception }\end{array}$ \\
\hline $\begin{array}{l}\text { Throw things } \\
\text { at partner }\end{array}$ & Swearing & $\begin{array}{l}\text { Forcing a partner } \\
\text { to have sex without } \\
\text { the partner's desire }\end{array}$ \\
\hline Push & $\begin{array}{l}\text { Isolating partner from } \\
\text { the environment }\end{array}$ & \\
\hline Bite & Lie & \\
\hline $\begin{array}{l}\text { Using } \\
\text { weapons to } \\
\text { attack partner }\end{array}$ & Forbid couples to go & \\
\hline
\end{tabular}

a. Source: Education Center for Woman and Children/Pusat Pendidikan Untuk Perempuan dan Anak (PUPA) Bengkulu. 
Education Center for Women and Children (PUPA) Bengkulu provide the following tips to avoid dating violence, which are:

- Before deciding to have a close relationship with others, try to find out the background of the couple first. This is very important because it will affect the next relationship;

- Upholding the principle that dating violence cannot be tolerated;

- Start the relationship by building a mutual commitment to respect each other, and no excuse for dating violence;

- You should think twice if during a date you feel that something violates your mutual commitment and violates your principles;

- Show confidence. Even though you are a girl, that doesn't mean you are passive. If you have something to say about your relationship, it should be discussed;

- If you experience violence, remember your life principle, that dating violence cannot be tolerated. You should stay away from your partner;

- If you feel hard to get out from your partner's domination, make plans to save yourself, seek help from those closest to you, and don't be afraid to speak up;

- Collect evidence of violence, such as photos, sound/video recordings, witness statements, etc;

- Violence committed by the perpetrator is a criminal act, so you can report it directly to the Police (PPA unit);

- As victims of violence, we can also ask National Commission on Violence against Women for assistance by calling the number: 021-3903963. If you need legal assistance, you are allowed to contact P2TP2A or Law Firm in Bengkulu, and if you need psychological recovery, you can contact P2TP2A in your area, or other psychological counseling service institutions.

5) Views From Child in Bengkulu

The motives of dating violence found in this study from respondents RY (17 years), WP (16 years), VP (14 years) are because:

- Jealousy;

- Not taking care of each other;

- Disobey;

- Economic needs

Dating violence is divided into two categories, which are physical violence and non-physical violence.
Physical violence is constructed as beatings and sexual harassment. Meanwhile, non-physical violence is classified as insults, unwanted attention, humiliation, and always considered incompetent. Dating according in RY (17 years), WP (16 years), VP (14 years) view is the way to increase motivation to learn, willingness to have close friends and pour out their hearts, and they also state that dating as a part of their existence. According to RY (17 years), WP (16 years), VP (14 years) they said that their motivation for dating had become a trend.

The phenomenon of RY (17 years), WP (16 years), VP (14 years) can be seen as part of self-existence as stated by Abraham H. Maslow that "Humans have several basic needs that must be met in stages where a person will move forward in the phase of higher needs when it has met the current basic needs. Physiological needs such as eating, drinking, shelter, including the need to love and to give and receive attention".

Based on an interview, they spell out that dating violence usually begins with emotional violence and words then followed by physical or sexual violence by a partner. The cause of dating violence is emotions that cannot be controlled properly because the partner is not mature yet. Other factors are a history of violence in the partner's family, feelings of inferiority or low selfesteem, understanding that violence will solve problems, and personality that tends to exploit partners.

According to respondents, although both a boy and girls can be victims or perpetrators, girls are more vulnerable to sexual violence and serious suffering as a result of dating violence. A girl who experiences violence has a greater tendency to forgive the abuser and continue the relationship as before.

Respondents state that it is necessary to build awareness that violence is not normal in a dating relationship. There must be a clear understanding regarding dating violence (especially sexual violence) that can reach those who are vulnerable to becoming victims. Living safe and free from violence is one of the points of universal human rights. Dating violence is all forms of action that consist of coercion, pressure, destruction, and physical and psychological abuse that occur in a relationship. Dating violence can be conducted by both a boy and a girl. Dating violence is formed in many behaviors, those behavior affects both psychologically and physically. In contrast to physical effects that can be identified, psychological effects are very difficult to recognize by the victims.

\section{B. Obstacles to Protect Children as Victims of Dating Violence in Bengkulu}

There are several obstacles in protecting children as victims of dating violence in Bengkulu. These include the following:

- Economic Difficulties, the economic condition of the victim who experiences dating violence is 
unable to litigate due to limited funds to hire an Advocate/Legal Counsel in resolving cases of dating violence;

- Feelings of immature children, this caused they cannot determine the act of dating violence is an act that violates the law and can be subject to criminal sanctions;

- People know about the dating violence phenomenon, but do not care, do not dare, and are afraid to make a report or complaint about it to the authorities, either to the police, legal institutions, or other institutions, or local community self-help;

- Lack of legal knowledge of the community about what should be done by the victim as an object of dating violence;

- There is still a strong sense of tolerance given by the victim to the perpetrator. Dating violence is often resolved amicably by both parties;

- In cases of sexual violence in a relationship, there are often obstacles in the legal process. This happens because law enforcement officials still view or assume that the incident occurred because of a good relationship between the victim and the perpetrator. The apparatus should view that the chances of women becoming victims of sexual violence are higher because of the power relations used by the perpetrators. The existence of this power relation makes the perpetrators assume that women are theirs who can be treated as they wish. This includes deceit, trickery, promises, lure, and various acts of domination by the perpetrator against the victim. Ultimately this is forced the victim to obey the perpetrator's wish.

The efforts of legal protection institutions or advocacy institutions in creating good law enforcement, especially in protecting children as victims of dating violence, really need supporting factors to create good and effective legal protection. Priority efforts in enforcing the protection of children as victims of Dating Violence are among others:

- Law Factor;

- Law Enforcement Officials Factor;

- Factors of Facilities that Support Law Enforcement;

- Society Factor;

- Culture Factor.

\section{Closing}

\section{A. Summary}

Based on the results of research and discussion, it can be concluded as follows:
- All types of dating violence can be subject to criminal sanctions, if the children as the victim have not reached 18 years (not yet an adult) then the perpetrator can be charged with Article $76 \mathrm{C}$ relating to Article 80 paragraph (1) Law Number 35 of 2014 concerning amendments to Law Number 23 of 2002 concerning Child Protection. However, if the perpetrators are 18 years old or older, then you litigate as regulated in Chapter XX of the Criminal Code (KUHP) such as Ordinary Persecution (Article 351 of the Criminal Code), Minor abuse (Article 352 of the Criminal Code), and Severe Abuse (Article 354 of the Criminal Code) and other forms of violence can also be imposed such as obscenity (Article 289-296 of the Criminal Code), Sexual Harassment (Article 281-283), and for Crimes Against Modesty (Article 532- 533), can also be charged with the Act Number 44 of 2008 concerning Pornography;

- There are several obstacles in protecting children as victims of dating violence in Bengkulu such as Economic Difficulties, Feelings of immature children, People knowing about the dating violence phenomenon, but do not care, Lack of legal knowledge of the community about what should be done by the victim as an object of dating violence, There is still a strong sense of tolerance given by the victim to the perpetrator, law enforcement officials still view or assume that the incident occurred because of a good relationship between the victim and the perpetrator. Those become an obstacle to law enforcement against dating violence.

\section{B. Recommendation}

Based on these conclusions, the authors suggest the following:

- It is hoped that there will be serious steps from law enforcement officials and related parties to pay attention to the protection regarding dating violence in Bengkulu jurisdiction, both preventive and repressive;

- Strengthen legal socialization on violent issues, especially dating violence, because children have not understood this issue yet;

- Academic institutions can give basic knowledge for students relating to what is the form of violence and how to avoid violence.

\section{ACKNOWLEDGMENT}

Through various opportunities and enlightenment during the discussion and preparation of a written review on the Children Protection towards Dating Violence in Bengkulu, thus encouraging for writers to study and examine the issue. The author would like to thank, to: 
- Rector and all leaders of the University of Lampung;

- ULICoSS Committee of 2021;

- The Dean and all the Heads of the Faculty of Law, University of Bengkulu;

- Fellow Lecturers and Educators at the Faculty of Law, Bengkulu University, and others.

\section{REFERENCES}

[1] The Law Number 23 of 2002 concerning Children Protection, State Gazette of the Republic of Indonesia Year 2002 Number 109.
[2] N. Zuhriyah, Konvensi Hak Perempuan. Malang: PSW UMM. 2002. p. 5.

[3] R. Saraswati, 2009, Hukum Perlindungan Anak Di Indonesia, PT. Citra Aditya Bakti, Bandung, p.1.

[4] Article 1, Definition of the Child, Convention on the Rights of the Child. 1989.

[5] K. Kartono. Psikologi Anak (Psikologi Perkembangan). Bandung: CV Mandar Maju. 1995.

[6] Z. J. Fernando. Alert! Dating Violence. DutaWarta.com, Bengkulu, access on Saturday, March 21st, 2020.

[7] Z. Asikin. Pengantar Metode Penelitian Hukum. Jakarta: Raja Grafindo Persada. 2004. 